\title{
Chemical composition and antibacterial activity of essential oils from Citrus aurantifolia leaves and fruit peel against oral pathogenic bacteria
}

\author{
RAIANE S. LEMES ${ }^{1}$, CASSIA C.F. ALVES ${ }^{1}$, ELISÂNGELA B.B. ESTEVAM ${ }^{1}$, \\ MARIANA B. SANTIAGO ${ }^{2}$, CARLOS H.G. MARTINS ${ }^{2}$, TAINÁ C.L. DOS \\ SANTOS $^{3}$, ANTÔNIO E.M. CROTTI ${ }^{3}$ and MAYKER L.D. MIRANDA ${ }^{4}$ \\ ${ }^{1}$ Instituto Federal de Educação, Ciência e Tecnologia Goiano, Campus Rio Verde, \\ Avenida Sul Goiana, s/n, Zona Rural, 75901-970 Rio Verde, GO, Brazil \\ ${ }^{2}$ Centro de Pesquisa em Ciências Exatas e Tecnologia, Universidade de Franca, Avenida Dr. \\ Armando de Salles Oliveira, 201, Parque Universitário, 14404-600 Franca, SP, Brazil \\ ${ }^{3}$ Departamento de Química, Faculdade de Filosofia, Ciências e Letras de Ribeirão Preto, Universidade de \\ São Paulo, Avenida Bandeirantes, 3900, Monte Alegre, 14049-900 Ribeirão Preto, SP, Brazil \\ ${ }^{4}$ Instituto Federal de Educação, Ciência e Tecnologia do Sul de Minas Gerais, Campus Pouso Alegre, \\ Avenida Maria da Conceição Santos, 900, Parque Real, 37550-000 Pouso Alegre, MG, Brazil
}

Manuscript received on October 21, 2017; accepted for publication on December 20, 2017

\begin{abstract}
Tooth decay is a major public health problem which affects a large number of people in several countries. Even though more than 700 bacterial species have been detected in the oral cavity, Streptococcus and Lactobacillus stand out as the genera that cause tooth decay and other periodontal diseases. In this study, essential oils from Citrus aurantifolia leaves (CL-EO) and fruit peel (CP-EO) were obtained by hydrodistillation by a Clevenger-type apparatus whereas their chemical composition was analyzed by gas chromatography-flame ionization detector (GC-FID) and gas chromatography-mass spectrometry (GC-MS). Limonene (77.5\%), linalool (20.1\%), citronellal (14.5\%) and citronellol (14.2\%) were the main constituents found in the essential oils from C. aurantifolia leaves and fruit peel. Antibacterial activity of essential oils was evaluated in terms of its minimum inhibitory concentration (MIC) values by the broth microdilution method in 96-well microplates. Both CL-EO and CP-EO displayed some activity against all oral pathogens under investigation; MIC values ranged from 20 to $200 \mu \mathrm{g} / \mathrm{mL}$. CLEO and CP-EO not only had promising activity against Streptococcus mutans (MIC $=20 \mu \mathrm{g} / \mathrm{mL}$ ) and Lactobacillus casei $(31.25 \mu \mathrm{g} / \mathrm{mL})$, but also displayed antibacterial activity against all studied cariogenic bacteria. Efficacy of essential oils against $S$. mutans and $L$. casei is noteworthy and should be further investigated.
\end{abstract}

Key words: Citrus aurantifolia, limonene, cariogenic bacteria, essential oils, oral pathogens.

\section{INTRODUCTION}

The high prevalence of tooth decay worldwide has

Correspondence to: Mayker Lazaro Dantas Miranda

E-mail: mayker.miranda@ifsuldeminas.edu.br made the World Health Organization consider it a severe public health problem which affects people of all ages. Brushing and flossing are the most effective methods to remove microorganisms from 
the tooth surface and prevent tooth decay and gum diseases (Melo et al. 2017). Chlorhexidine has been widely applied to this purpose because it displays anticariogenic properties. However, its regular use in oral care products often leads to several side effects (Melo et al. 2017).

Citrus aurantifolia is a species that belongs to the family Rutaceae which has about 150 genera and 1600 species that are broadly distributed in tropical, subtropical and temperate zones around the world. In Brazil, the family Rutaceae is represented by about 29 genera and 182 species; some of them have economic importance (Campelo et al. 2013). Citrus is a genus that comprises about 70 species of subshrubs and shrubs which may be either grown or spontaneously found in Germany, Spain, Mexico, Venezuela, Cuba, Jamaica, Ecuador and in many regions in Brazil (Campelo et al. 2013).

Species of the genus Citrus have been highlighted because they are rich in essential oils which are very versatile and often used as flavorings in several goods, such as beverages, soaps, cosmetics and household products. Their essential oils have also been frequently used in medical treatments due to their antimicrobial, antifungal, antibacterial and antiparasitic properties (Estevam et al. 2016). Many recent studies that have attempted to determine the chemical composition of essential oils extracted from $C$. aurantifolia. Researchers have noted that the components of these oils display large intraspecific chemical variation (Tundis et al. 2012, Amorim et al. 2016).

The species $C$. aurantifolia has been known because it exhibits important biological activities, such as antimicrobial activity against several pathogens - Staphylococcus aureus, Escherichia coli, Klebsiella pneumonia, Pseudomonas spp, Aspergillus niger and Candida albicans antiaflatoxigenic and anticancer activities (Aibinu et al. 2007, Abyaneh et al. 2009, Pathan et al. 2012, Narang and Jiraungkoorskul 2016). However, anticariogenic activity of essential oils from $C$. aurantifolia against oral pathogens has not been investigated yet.

As part of an ongoing project on the biological activity of essential oils (Xavier et al. 2016, Lemes et al. 2017), this study investigated the chemical constituents and the antibacterial activity of essential oils from Citrus aurantifolia leaves and fruit peel against a representative panel of cariogenic bacteria.

\section{MATERIALS AND METHODS}

\section{PLANT MATERIAL}

C. aurantifolia leaves and fruit peel were collected in the Cerrado region in Rio Verde, Goiás, Brazil, in July 2015. The plant was identified by the botanist Erika Amaral and a sample was deposited at the Herbarium Jataiense Professor Germano Guarim Neto at exsiccate number HJ 7444.

\section{EXTRACTION OF ESSENTIAL OILS}

Samples of C. aurantifolia fresh leaves and fruit peel were subjected to hydrodistillation for 3 hours by a Clevenger-type apparatus. In order to carry out the analysis, $300 \mathrm{~g}$ plant material was divided into three 100-g samples and $500 \mathrm{~mL}$ distilled water was added to each sample. After manual collection of the essential oil samples, traces of remaining water in the oils were removed with anhydrous sodium sulfate, which was followed by filtration. The extraction procedure was done in triplicate. The isolated oil was stored under refrigeration up to the analysis and test. Yields $(\mathrm{w} / \mathrm{w})$ were calculated from fresh leaf and fruit peel weight and expressed as the average of the triplicate analyses.

\section{IDENTIFICATION OF THE CHEMICAL} COMPOSITION OF THE ESSENTIAL OILS

Gas Chromatography (GC)analyses were performed by a Shimadzu GC2010 Plus gas chromatograph equipped with an AOC-20s autosampler and fitted with fitted with Flame Ionization Detector (FID) 
and a data-handling processor. An Rtx-5 (Restek Co., Bellefonte, PA, USA) fused silica capillary column $(30 \mathrm{~m}$ x $0.25 \mathrm{~mm}$ i.d. x $0.25 \mu \mathrm{m}$ film thickness) was employed. Operation conditions were as follows: column temperature programmed to rise from 60 to $240{ }^{\circ} \mathrm{C}$ at $3{ }^{\circ} \mathrm{C} / \mathrm{min}$ and then hold at $240{ }^{\circ} \mathrm{C}$ for $5 \mathrm{~min}$; carrier gas $=\mathrm{He}(99.999 \%)$, at $1.0 \mathrm{~mL} / \mathrm{min}$; injection mode; injection volume, 0.1 $\mu \mathrm{L}$ (split ratio of 1:10); and injector and detector temperatures $=240$ and $280{ }^{\circ} \mathrm{C}$, respectively. Relative concentrations of components were obtained by peak area normalization (\%). Relative areas were the average of triplicate GC-FID analyses.

GC-MS analyses were carried out by a Shimadzu QP2010 Plus (Shimadzu Corporation, Kyoto, Japan) system equipped with an AOC20i autosampler. The column was an RTX-5MS (Restek Co., Bellefonte, PA, USA) fused silica capillary one ( $30 \mathrm{~m}$ x $0.25 \mathrm{~mm}$ i.d. x $0.25 \mu \mathrm{m}$ film thickness). Electron ionization mode occurred at 70 eV. Helium (99.999\%) was employed as the carrier gas at a constant flow of $1.0 \mathrm{~mL} / \mathrm{min}$. The injection volume was $0.1 \mu \mathrm{L}$ (split ratio of 1:10). Injector and ion-source temperatures were set at 240 and 280 ${ }^{\circ} \mathrm{C}$, respectively. The oven temperature program was the same as the one used for GC. Mass spectra were taken at a scan interval of $0.5 \mathrm{~s}$, in the mass range from 40 to $600 \mathrm{Da}$.

Identification of volatile components of C. aurantifolia leaves and fruit peel (Table I) was based on their retention indices on an RTX5MS capillary column under the same operating conditions as the ones found in the case of GC, related to a homologous series of $n$-alkanes $\left(\mathrm{C}_{8}\right.$ $\mathrm{C}_{20}$ ). Structures were computer-matched with the Wiley 7, NIST 08 and FFNSC 1.2 spectra libraries and their fragmentation patterns were compared with literature data (Adams 2007).
BACTERIAL STRAINS AND ANTIMICROBIAL ASSAYS

In vitro antimicrobial activities of CL-EO and $\mathrm{CP}-\mathrm{EO}$ were determined by minimum inhibitory concentration (MIC) assays which were based on the broth microdilution method (CLSI 2009). Streptococcus salivarius (ATCC 25975), Streptococcus sobrinus (ATCC 33478), Streptococcus mutans (ATCC 25175), Streptococcus mitis (ATCC 49456), Streptococcus sanguinis (ATCC 10556) and Lactobacillus casei (ATCC 11578) were the standard strains in the assays. Initially, bacteria were transferred to blood agar (Difco Labs, Detroit, MI, USA), and individual 24-h colonies were suspended in 10.0 $\mathrm{mL}$ tryptic soy broth (Difco). A spectrophotometer (Femto, São Paulo, SP, Brazil) at a wavelength $(\lambda)$ of $625 \mathrm{~nm}$ was used for standardizing the suspensions of each microorganism so as to match the transmittance of 81 , equivalent to 0.5 in the McFarland scale $\left(1.5 \times 10^{8} \mathrm{CFU} / \mathrm{mL}\right)$. Dilution of the standardized suspension generated the final concentration of $5 \times 10^{5} \mathrm{CFU} / \mathrm{mL}$. Essential oils (CL-EO and CP-EO) were dissolved in DMSO (Merck, Darmstadt, Germany) at $16.0 \mathrm{mg} / \mathrm{mL}$. Concentrations ranging from 4000 to $3.9 \mu \mathrm{g} /$ $\mathrm{mL}$ were achieved after dilution of essential oils in tryptic soy broth (Difco). After the dilutions, DMSO concentrations were between $4 \%$ and $0.0039 \%(\mathrm{v} / \mathrm{v})$. Negative controls, three inoculated wells with DMSO at concentrations ranging from 4 $\%$ to $1 \%$ and one non-inoculated well, free of any antimicrobial agent, were included. An inoculated well helped to test whether the broth was adequate for microorganisms to grow. The positive control was chlorhexidine dihydrochloride (CHD) (SigmaAldrich, St. Louis, MO, USA) at concentrations ranging from 5.9 to $0.115 \mu \mathrm{g} / \mathrm{mL}$, diluted in tryptic soy broth (Difco). Ninety-six-well microplates were 
sealed with parafilm and incubated at $37^{\circ} \mathrm{C}$ for 24 h. After that, $30 \mathrm{~mL}$ of an aqueous solution with $0.02 \%$ resazurin (Sigma-Aldrich, St. Louis, MO, USA) was added to each microplate well to indicate the viability of the microorganism (Palomino et al. 2002). The lowest concentration of the sample that inhibited microorganism growth (MIC value) was determined as the lowest concentrations of CL-EO and CP-EO that were able to prevent the resazurin solution from changing its color (Sarker et al. 2007). All assays were conducted in triplicate.

\section{RESULTS AND DISCUSSION}

Both analyses by GC-MS and GC-FID identified eighteen compounds in the essential oil from $C$. aurantifolia leaves and seventeen compounds in its essential oil from fruit peel, i.e., $99.5 \%$ and 99.2 $\%$ of the total compounds, respectively (Table I). Table I shows these constituents with their retention indices, retention times and percentages.

Essential oils from $C$. aurantifolia leaves and fruit peel showed high yield (w/w on fresh weight basis), i.e., $2.5 \%$ and $3.0 \%$, respectively. Both analyses by GC-FID and GC-MS revealed that monoterpene hydrocarbons $(84.6 \%)$ were the main constituents of CP-EO and oxygenated monoterpenes $(57.6 \%)$ were the main constituents of CL-EO, whereas limonene $(77.5 \%, 1)$, linalool $(20.1 \%, 2)$, citronellal $(14.5 \%, 3)$ and citronellol $(14.2 \%, 4)$ were their major constituents (Figure 1, Table I).

The chemical composition of essential oils from C. aurantifolia leaves and fruit peel was similar to the ones from other species of Citrus, such as $C$. limonia and $C$. reticulata previously described in the literature since they all have the same major constituents (Martins et al. 2017). Limonene was found at large amounts in C. aurantifolia leaves and fruit peel, besides being the major constituent of essential oils from $C$. sinensis, C. latifolia and C. limonia (Eldahshan and Halim 2016, Estevam et al. 2016). Therefore, it should be highlighted that, since essential oils from $C$. aurantifolia found in southwestern Goiás are rich in limonene, linalool, citronellal and citronellol, they may be a new prospecting source of these bioactive compounds.

Previous reports on the essential oil obtained from others $C$. aurantifolia specimens have indicated that terpenes predominate in the oil, and that the chemical composition of the essential oil varies significantly depending on the origin of the plant. Samples from Italy contained limonene, $\beta$-myrcene, $\beta$-pinene, $\gamma$-terpinene, citral and $\beta$-bisabolene as the major compounds (Tundis et al. 2012, Spadaro et al. 2012). $\beta$-pinene and limonene were also the major components in an essential oil sample collected in South Korea (Hong et al. 2017). The chemical composition found in this study is similar to that previously reported by a study which quantified and identified the main chemical compounds of the volatile oil extracted from C. aurantifolia grown in Rio de Janeiro State (Amorim et al. 2016).

Plant derivatives, such as extracts, essential oils and pure compounds have already been evaluated regarding their antimicrobial effects against oral pathogenic agents. As a result, they have attracted the interest of research groups since they can be applied to the development of new solutions to mouth rinse used for oral hygiene (Estevam et al. 2016). However, reports of antimicrobial activity

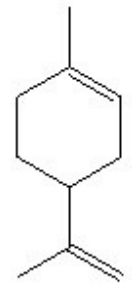

1

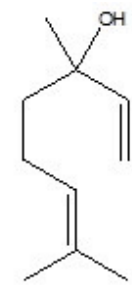

2

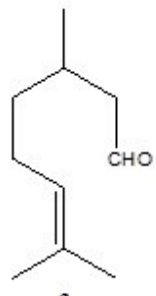

3

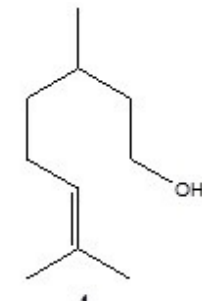

Figure 1 - Chemical structures of major constituents of essential oils from C. aurantifolia: limonene (1), linalool (2), citronellal (3) and citronellol (4). 
TABLE I

Chemical composition of essential oils from Citrus aurantifolia leaves (CL-EO) and fruit peel (CP-EO).

\begin{tabular}{|c|c|c|c|c|c|}
\hline \multirow{2}{*}{$R T(\min )$} & \multirow{2}{*}{ Compounds } & \multirow{2}{*}{$\boldsymbol{R} \boldsymbol{I}_{\text {exp }}$} & \multirow{2}{*}{$\boldsymbol{R}_{\text {lit }}$} & \multicolumn{2}{|c|}{$R A \%$} \\
\hline & & & & CL-EO & CP-EO \\
\hline 6.28 & (Z)-Hex-3-en-1-ol & 853 & 851 & 1.1 & \\
\hline 9.09 & $\alpha$-Pinene & 935 & 934 & & 0.9 \\
\hline 10.78 & Sabinene & 975 & 974 & & 0.3 \\
\hline 11.57 & Myrcene & 993 & 991 & 1.4 & 4.4 \\
\hline 13.82 & Limonene & 1043 & 1040 & 32.7 & 77.5 \\
\hline 14.32 & trans- $\beta$-Ocimene & 1054 & 1050 & 2.7 & 0.9 \\
\hline 14.81 & $\gamma$-Terpinene & 1065 & 1062 & & 0.6 \\
\hline 17.00 & Linalool & 1106 & 1107 & 20.1 & 3.5 \\
\hline 18.59 & Limonene oxide & 1133 & 1133 & 0.5 & \\
\hline 19.97 & Isopulegol & 1141 & 1145 & 1.0 & \\
\hline 19.31 & Citronellal & 1158 & 1153 & 14.5 & 3.2 \\
\hline 21.13 & $\alpha$-Terpineol & 1184 & 1185 & 0.6 & 0.7 \\
\hline 21.34 & Unknown & 1198 & 1198 & & 0.1 \\
\hline 22.87 & Citronellol & 1230 & 1228 & 14.2 & 2.0 \\
\hline 23.53 & Neral & 1242 & 1240 & 2.1 & \\
\hline 24.12 & Geraniol & 1253 & 1255 & 1.0 & \\
\hline 24.86 & Geranial & 1271 & 1270 & 2.6 & \\
\hline 28.40 & Citronellyl acetate & 1354 & 1354 & 1.0 & \\
\hline 31.30 & trans- $\beta$-Caryophyllene & 1420 & 1418 & 2.0 & 0.4 \\
\hline 31.92 & $\alpha$-trans-Bergamotene & 1435 & 1434 & 0.8 & 1.3 \\
\hline 33.85 & Germacrene D & 1481 & 1480 & & 1.5 \\
\hline 34.48 & Bicyclogermacrene & 1499 & 1494 & & 0.2 \\
\hline 34.64 & Unknown & 1550 & 1549 & & 0.2 \\
\hline 34.89 & $\beta$-Bisabolene & 1510 & 1509 & 0.9 & 1.5 \\
\hline \multirow[t]{8}{*}{37.92} & Caryophyllene oxide & 1583 & 1581 & 0.3 & \\
\hline & Monoterpene hydrocarbons & & & 36.8 & 84.6 \\
\hline & Oxygenated monoterpenes & & & 57.6 & 9.4 \\
\hline & Sesquiterpene hydrocarbons & & & 3.7 & 4.9 \\
\hline & Oxygenated sesquiterpenes & & & 0.3 & \\
\hline & Others & & & 1.1 & \\
\hline & Not identified & & & & 0.3 \\
\hline & Total & & & 99.5 & 99.2 \\
\hline
\end{tabular}

$\boldsymbol{R I}_{\text {exp }}$ : Retention index relative to $n$-alkanes $\left(\mathrm{C}_{8}-\mathrm{C}_{20}\right)$ on the Rtx-5MS column; $\boldsymbol{R I}_{\text {lit }}:$ Retention index found in the literature (Adams 2007). $\boldsymbol{R} \boldsymbol{A} \%$ : relative area.

of natural products against oral pathogens are still scarce (Estevam et al. 2016).

Concerning the antibacterial activity of essential oils from $C$. aurantifolia leaves and fruit peel, the in vitro anticariogenic activity (MIC values, see Table II) of CL-EO and CP-EO were evaluated against a representative panel of cariogenic bacteria and results were compared with chlorhexidine dihydrochloride as a positive control. According to the literature, MIC values below 100 $\mu \mathrm{g} / \mathrm{mL}$, between 100 and $500 \mu \mathrm{g} / \mathrm{mL}$ and between 500 and $1000 \mu \mathrm{g} / \mathrm{mL}$ correspond to promising, 
TABLE II

Anticariogenic activity of essential oils from $C$. aurantifolia (CL-EO and CP-EO) against oral bacteria under study.

\begin{tabular}{cccc}
\hline \multirow{2}{*}{ Bacteria } & \multicolumn{3}{c}{$\begin{array}{c}\text { Minimum inhibitory } \\
\text { concentration (MIC) }-\boldsymbol{\mu g} / \mathbf{m L}\end{array}$} \\
\cline { 2 - 4 } & CL-EO & CP-EO & CHD* \\
\hline Streptococcus salivarius & 200 & 200 & 0.922 \\
S. mutans & 20 & 20 & 0.922 \\
S. mitis & 200 & 100 & 3.688 \\
S. sanguinis & 200 & 100 & 0.922 \\
S. sobrinus & 100 & 200 & 0.922 \\
Lactobacillus casei & 31.25 & 31.25 & 1.844 \\
\hline
\end{tabular}

CHD*: chlorhexidine dihydrochloride (positive control).

moderate and weak activities, respectively, whereas MIC values above $1000 \mu \mathrm{g} / \mathrm{mL}$ denote inactivity (Gibbons 2004, Rios and Recio 2005, Saleem et al. 2010). Based on these criteria, CL-EO and CP-EO displayed moderate activity against Streptococcus mitis, $S$. sanguinis, $S$. sobrinus and $S$. salivarius. On the other hand, CL-EO and CP-EO had promising activity against $S$. mutans and Lactobacillus casei (Table II).

Several mechanisms have been proposed to explain the antimicrobial activity of essential oils (Oliveira et al. 2016). Microbial growth inhibition by the activity of essential oils is due to direct damage caused to the integrity of cell membranes by lipophilic components of the essential oil, a fact that affects the maintenance of the cell $\mathrm{pH}$ and the balance of inorganic ions directly (Oliveira et al. 2016). Inhibitory effects of essential oils have also been described as consistent with the activity of monoterpenic and sesquiterpenic constituents in cell membranes while damage caused to the membrane is said to yield different effects on diverse microorganisms (Vieira et al. 2017). Correlation between the lipophilicity of oil constituents and the antimicrobial activity of essential oils has motivated researchers to investigate the antibacterial activity of some essential oils against cariogenic bacteria (Melo et al. 2017, Carneiro et al. 2017). In this study, CL-EO and CP-EO were found to display promising activity against $S$. mutans $(\mathrm{MIC}=20$ $\mu \mathrm{g} / \mathrm{mL}$ ) and L. casei $(\mathrm{MIC}=31.25 \mu \mathrm{g} / \mathrm{mL})$ (Table II). It is remarkable because $S$. mutans is one of the primary causes of tooth decay and its inhibition by natural compounds is unusual (Saleem et al. 2010).

Promising anticariogenic activity shown by essential oils from $C$. aurantifolia may be justified by their major constituents, i.e., limonene, linalool, citronellal and citronellol, whose antibacterial potential has already been reported by the literature (Valeriano et al. 2012, Millezi et al. 2014). In addition, Bezerra et al. (2013) stated that bacterial strains of $S$. mutans, S. oralis and S. salivarius were susceptible to the activity of phytoconstituents linalool, citronellol and limonene. In sum, antibacterial activity of CL-EO and CP-EO may also be correlated to other minor components that might either underline or even increase the activity of the major chemical constituents of these essential oils in a synergistic mechanism (Vieira et al. 2017). However, although the antimicrobial activity of CL-EO and CP-EO may be related to the lipophilicity of the monoterpenes thereof, the exact mechanism through which CL-EO and CPEO exert their antimicrobial activity is not clear and should be further investigated.

Findings of this study highlight that essential oils from Citrus aurantifolia leaves and fruit peel display interesting and promising antibacterial activity against some important cariogenic bacteria, such as $S$. mutans. As a result, CL-EO and CP-EO might be used as promising components of new oral care products because $S$. mutans is one of the main causes of oral disorders, such as tooth decay. Further studies that identify active chemical constituents of CL-EO and CP-EO and determine their antimicrobial mechanisms are underway.

\section{REFERENCES}

ABYANEH MR, GHAHFAROKHI MS, REZAEE MB, JAIMAND K, ALINEZHAD S, SABERI R AND 
YOSHINARI T. 2009. Chemical composition and antiaflatoxigenic activity of Carum carvi L., Thymus vulgaris and Citrus aurantifolia essential oils. Food Control 20: 1018-1024.

ADAMS RP. 2007. In Identification of Essential Oil Components by Gas Chromatography/Quadrupole Mass Spectroscopy, $4^{\text {th }}$ ed., Allured Publishing Corporation: Carol Stream, 804 p.

AIBINU I, ADENIPEKUN T, ADELOWOTAN T, OGUNSANYA T AND ODUGBEMI T. 2007. Evaluation of the antimicrobial properties of different parts of Citrus aurantifolia (Lime Fruit) as used locally. Afr J trad CAM 4: 185-190.

AMORIM JL, SIMAS DLR, PINHEIRO MMG, MORENO DAS, ALVIANO CS, SILVA AJR AND FERNANDES PD. 2016. Anti-inflammatory properties and chemical characterization of the essential oils of four Citrus species. PLoS ONE 11: e0153643.

BEZERRA LMD, FERREIRA GLS, SILVA ICG AND CASTRO RD. 2013. Atividade antibacteriana in vitro de fitoconstituintes sobre microrganismos do biofilme dentário. R Bras Ci Saúde 17: 79-84.

CAMPELO LML, SÁ CG, FEITOSA CM, SOUSA GF AND FREITAS RM. 2013. Constituintes químicos e estudos toxicológicos do óleo essencial extraído das folhas de Citrus limon Burn (Rutaceae). Rev Bras P1 Med 15: 708716.

CARNEIRO NS ET AL. 2017. Chemical composition, antioxidant and antibacterial activities of essential oils from leaves and flowers of Eugenia klotzschiana Berg (Myrtaceae). An Acad Bras Cienc 89: 1907-1915.

CLSI. 2009. Susceptibility testing of aerobic bacteria. Approved standard, $8^{\text {th }}$ ed., CLSI document M7-A8". Wayne, PA: NCCLS, 15 p.

ELDAHSHAN OA AND HALIM AF. 2016. Comparison of the composition and antimicrobial activities of the essential oils of green branches and leaves of Egyptian navel orange (Citrus sinensis (L.) Osbeck var. malesy. Chem Biodivers 13: 681-685.

ESTEVAM EBB ET AL. 2016. Composição química e atividades biológicas dos óleos essenciais das folhas frescas de Citrus limonia Osbeck e Citrus latifolia Tanaka (Rutaceae). Rev Virtual Quim 8: 1842-1854.

GIBBONS S. 2004. Anti-staphylococcal plant natural products. Nat Prod Rep 2004: 263-277.

HONG JH, KHAN N, JAMILA N, HONG YS, NHO EY, CHOI JY, LEE CM AND KIM KS. 2017. Determination of volatile flavour profiles of Citrus spp. fruits by SDE-GCMS and enantiomeric composition of chiral compounds by MDGC-MS. Phytochem Anal 28: 392-403.

LEMES RS, COSTA GCS, SILVA DCS, BECCENERI AB, BICALHO KU, MIRANDA MLD, DINIZ VSS AND CAZAL CM. 2017. Óleos essenciais dos frutos e folhas de Kielmeyera coriacea: atividade antitumoral e estudo químico. Rev Virtual Quim 9: 1245-1257.

MARTINS MHG ET AL. 2017. Schistosomicidal effects of the essential oils of Citrus limonia and Citrus reticulata against Schistosoma mansoni. Chem Biodivers 2017: e160094.

MELO DC, MIRANDA MLD, JÚNIOR WGF, ANDRADE PM, ALCOBA AET, SILVA TS, CAZAL CM AND MARTINS CHG. 2017. Anticariogenic and antimycobacterial activities of the essential oil of Siparuna guianensis Aublet (Siparunaceae). Orbital: Electron J Chem 9: 55-60.

MILLEZI AF, BAPTISTA NN, CAIXETA DS, ROSSONI DF, CARDOSO MG AND PICCOLI RH. 2014. Caracterização química e atividade antibacteriana de óleos essenciais de plantas condimentares e medicinais contra Staphylococcus aureus e Escherichia coli. Rev Bras P1 Med 16: 18-24.

NARANG N AND JIRAUNGKOORSKUL W. 2016. Anticancer activity of Key Lime, Citrus aurantifolia. Pharmacogn Rev 10: 118-122.

OLIVEIRA JD, ALVES CCF, MIRANDA MLD, MARTINS CHG, SILVA TS, AMBROSIO MALV, ALVES JM AND SILVA JP. 2016. Rendimento, composição química e atividades antimicrobiana e antioxidante do óleo essencial de folhas de Campomanesia adamantium submetidas a diferentes métodos de secagem. Rev Bras P1 Med 18: $502-$ 510.

PALOMINO JC, MARTIN A, CAMACHO M, GUERRA H, SWINGS J AND PORTAELS F. 2002. Resazurin microtiter assay plate: simple and inexpensive method for detection of drug resistence in Mycobacterium tuberculosis. Chemotherapy 46: 2720-2722.

PATHAN RK, GALI PR, PATHAN P, GOWTHAM T AND PASUPULETI S. 2012. In vitro antimicrobial activity of Citrus aurantifolia and its phytochemical screening. Asian Pac J Trop Dis 2: 328-331.

RIOS JL AND RECIO MC. 2005. Medicinal plants and antimicrobial activity. J Ethnopharmacol 100: 80-84.

SALEEM M, NAZIR M, ALI MS, HUSSAIN H, LEE YS, RIAZ N AND JABBAR A. 2010. Antimicrobial natural product: an update on future antibiotic drug candidates. Nat Prod Rep 27: 238-254.

SARKER SD, NAHAR L AND KUMARASAMY Y. 2007. Microtitre plate-based antibacterial assay incorporating resazurin as an indicator of cell growth, and its application in the in vitro antibacterial screening of phytochemicals. Methods 42: 321-324.

SPADARO F, COSTA R, CIRCOSTA C AND OCCHIUTO F. 2012. Volatile composition and biological activity of key lime Citrus aurantifolia essential oil. Nat Prod Commun 7: 1523-1526.

TUNDIS R, LOIZZO MR, BONESI M, MENICHINI F, MASTELLONE V, COLICA C AND MENICHINI F. 
2012. Comparative study on the antioxidant capacity and cholinesterase inhibitory activity of Citrus aurantifolia Swingle, C. aurantium L., and C. bergamia Risso and Poit. peel essential oils. J Food Sci 77: H40-46.

VALERIANO C, PICCOLI RH, CARDOSO MG AND ALVES E. 2012. Atividade antimicrobiana de óleos essenciais em bactérias patogênicas de origem alimentar. Rev Bras P1 Med 14: 57-67.

VIEIRA TM, DIAS HJ, MEDEIROS TCT, GRUNDMANN CO, GROPPO M, HELENO VCG, MARTINS CHG, CUNHA WR, CROTTI AEM AND SILVA EO. 2017.
Chemical composition and antimicrobial activity of the essential oil of Artemisia absinthium (Asteraceae) leaves. J Essent Oil Bear P1 20: 123-131.

XAVIER MN, ALVES JM, CARNEIRO NS, SOUCHIE EL, SILVA EAJ, MARTINS CHG, AMBROSIO MALV, EGEA MB, ALVES CCF AND MIRANDA MLD. 2016. Composição química do óleo essencial de Cardiopetalum calophyllum Schltdl. (Annonaceae) e suas atividades antioxidante, antibacteriana e antifúngica. Rev Virtual Quim 8: 1433-1448. 